\title{
Decay of Mycobacterium bovis in whole milk submitted to pasteurization parameters
}

\section{Decaimento de Mycobacterium bovis em leite integral submetido aos parâmetros de pasteurização}

\author{
Leandro Ribeiro ${ }^{1}$; Maurício Roberto Tosti Narciso ${ }^{1}$; Tatiane Hoshida Felipe ${ }^{1}$; \\ Karina Ramirez Starikoff ${ }^{1}$; Gisele Oliveira de Souza ${ }^{1}$. José Soares Ferreira Neto ${ }^{2}$; \\ Fernando Ferreira ${ }^{2}$; Marcos Amaku ${ }^{2}$; Ricardo Augusto Dias²; \\ Vítor Salvador Picão Gonçalves ${ }^{3}$; Marcos Bryan Heinemann²; \\ José Henrique Hildebrand Grisi-Filho ${ }^{2}$; Evelise Oliveira Telles ${ }^{2 *}$
}

\begin{abstract}
Parameters for milk pasteurization were established a long time ago, considering the thermal resistance of Mycobacterium bovis, and the systematic adoption of this process has drastically reduced the incidence of human tuberculosis caused by this pathogen. However, more recently, molecular methods have allowed the identification of genetic variations in this bacterium that may lead to greater thermal resistance. The aim of this study was to investigate whether genetic variation leads to variation in the death pattern of this bacterium during the milk pasteurization process. Samples of UHT (ultrahigh temperature)-treated whole milk were artificially contaminated with four different Mycobacterium bovis spoligotypes and were subjected to pasteurization by low-temperature long-time (LTLT) and high-temperature short-time (HTST) treatments. The M. bovis spoligotypes were quantified (Colony Forming Unit per milliliter of milk) before and during the thermal process. The decay of the pathogen was quantified by calculating the difference between the measurements at the beginning and at the end of the thermal treatment. The data demonstrated that the LTLT and HTST pasteurization processes considerably reduced the M. bovis load in the milk; however, the bacterium was not eliminated. There was no difference in the thermal resistance of the spoligotypes tested or in the efficiency of pasteurization processes (LTLT versus HTST). However, heating phase was more effective in reducing the $M$. bovis load than the target temperature maintenance phase.
\end{abstract}

Key words: Batch pasteurization. Bovine tuberculosis. Flow pasteurization. Mycobacterium bovis. Thermal death.

\section{Resumo}

Os parâmetros para a pasteurização do leite foram estabelecidos há muito tempo, considerando a resistência térmica de Mycobacterium bovis e a adoção sistemática deste processo reduziu drasticamente a incidência de tuberculose humana causada por este patógeno. Entretanto, mais recentemente, métodos

\footnotetext{
${ }^{1}$ Discentes, Faculdade de Medicina Veterinária e Zootecnia, Universidade de São Paulo, USP, São Paulo, SP, Brasil. E-mail: leandro@ lgmassessoria.com.br; pepenarciso@gmail.com; tatianehoshida@gmail.com; kastarikoff@yahoo.com.br; ginutri@usp.br

${ }^{2}$ Profs., Faculdade de Medicina Veterinária e Zootecnia, Universidade de São Paulo, USP, São Paulo, SP, Brasil. E-mail: jsoares@ vps.fmvz.usp.br; fernando@vps.fmvz.usp.br; amaku@vps.fmvz.usp.br; dias@vps.fmvz.usp.br; marcosbryan@usp.br; grisi@ vps.fmvz.usp.br; bufalo@usp.br

${ }^{3}$ Prof., Faculdade de Agronomia e Medicina Veterinária, Universidade de Brasília, UnB, Brasília, DF, Brasil. E-mail: vitorspg@ unb.br

* Author for correspondence
} 
moleculares permitiram a identificação de variações genéticas nesta bactéria que podem levar a uma maior resistência térmica. $\mathrm{O}$ objetivo deste estudo foi investigar se a variação genética apresenta modificação no padrão de morte da bactéria durante o processo de pasteurização do leite. Amostras de leite tratadas por UHT (ultra-alta temperatura) integral foram contaminadas com quatro diferentes espoligotipos de Mycobacterium bovis e foram submetidos ao tratamento por temperatura baixa e tempo longo (LTLT) e temperatura alta e tempo curto (HTST). Os espoligotipos M. bovis foram quantificados (Unidades Formadoras de colônias por mililitro de leite) antes e durante o processo térmico. A diminuição do patógeno foi quantificada através do cálculo da diferença entre as medições no início e no fim do tratamento térmico. Os dados demonstraram que os processos de pasteurização HTST e LTLT reduziram consideravelmente a carga de $M$. bovis no leite; no entanto, a bactéria não foi eliminada. Não houve diferença na resistência térmica dos espoligotipos testados nem na eficiência dos processos de pasteurização (HTST versus LTLT). Entretanto, a fase de aquecimento foi mais eficaz na redução da carga de $M$. bovis que a fase de manutenção da temperatura-alvo.

Palavras-chave: morte térmica, Mycobacterium bovis, pasteurização lenta, pasteurização rápida.

\section{Introduction}

Mycobacterium bovis is the agent of bovine tuberculosis, a zoonotic disease that can be transmitted through milk. When the infection occurs via the digestive tract, lesions on the pharyngeal and mesenteric lymph nodes are common (SINHA, 1994).

Milk contamination can occur directly because of tuberculosis of the udder or indirectly through the excreta and secretions of infected animals, dust contaminated by their secretions and excreta, the hands of the milker, etc. (SINHA, 1994).

In Brazil, recent studies carried out in 13 states, which hold $75 \%$ of the Brazilian cattle population, showed prevalence of infected herds with tuberculosis among $0.36 \%$ of the Federal District and $9.0 \%$ of São Paulo (BAHIENSE et al., 2016; BARBIERI et al., 2016; DIAS et al., 2016; GALVIS et al., 2016; GUEDES et al., 2016; LIMA et al., 2016; NÉSPOLI et al., 2016; QUEIROZ et al., 2016; RIBEIRO et al., 2016; ROCHA et al., 2016; SILVA et al., 2016; VELOSO et al., 2016; VENDRAME et al., 2016).

In Brazil and other countries, data regarding the occurrence of $M$. bovis in milk and dairy products are scarce and less precise, and reports of a low isolation frequency are common (KAHLA et al., 2011; LEITE et al., 2003; PEREZ et al., 2002; ZUMÁRRAGA et al., 2012). Factors that contribute to this low isolation frequency include the intermittent excretion of the bacillus into the milk (PEREZ et al., 2002) and the observation that not all infected cows eliminate the bacteria via this route. Kahla et al. (2011) determined that only 5\% of the cows testing positive for the single cervical test eliminated $M$. bovis through the milk, whereas Perez et al. (2002) reported that up to $30 \%$ of the infected cows eliminated the bacterium in this manner. In addition, it is possible that mixing contaminated milk with uncontaminated milk from healthy cows and slow growth of the agent contribute to the reduced initial contamination levels in milk, as does the lack of analytical techniques for the detection of low levels of contamination (MESSELHÄUSSER et al., 2012).

Countries that adopted a broad and systematic policy for the pasteurization of milk observed a significant decrease in the incidence of human tuberculosis caused by M. bovis (SINHA, 1994). The time and temperature parameters for the pasteurization process were established after studying the thermal resistance of Mycobacterium tuberculosis var. bovis (NORTH; PARK, 1927; OLDENBUSCH et al., 1930) and Coxiella burnetti (HUEBNER et al., 1948), which are the non-sporeforming bacteria most resistant to heat and are natural contaminants of milk. It is important to emphasize that $M$. bovis was later classified as an individual species by Karlson and Lessel (1970). 
In Brazil, the pasteurization of milk has been mandatory since the early 1950s, and both HTST (high-temperature short-time, $72-75^{\circ} \mathrm{C}$ for $15-20$ s) and LTLT (low-temperature long-time, $62-65^{\circ} \mathrm{C}$ for $30 \mathrm{~min}$ ) pasteurization processes are allowed. Additionally, enzymatic criteria are used to control the process, which must inactivate alkaline phosphatase and maintain the activity of peroxidase (BRASIL, 1952).

In the first studies, the thermal resistance of mycobacteria was evaluated by inoculating guinea pigs with milk treated with different combinations of time and temperature, followed by the observation of lesions at necropsy (NORTH; PARK, 1927; OLDENBUSCH et al., 1930). In later studies, in vitro agent quantification methods were used to evaluate $M$. bovis and other mycobacteria (GRANT et al., 1996; HARRINGTON; KARLSON, 1965; KELLS; LEAR, 1960). In the past 20 years, studies have focused on Mycobacterium avium subspecies paratuberculosis (SUNG; COLLINS, 1998; GRANT et al., 1996; GRANT et al., 2005; MCDONALD et al., 2005; PAVLAS, 1990; PEARCE et al., 2001), which causes Johne's disease in cattle and is possibly associated with Crohn's disease in humans (RUDOLER, 1998).

The advent of molecular techniques, which allow the differentiation of genetic groups within microorganism species, leads to new scientific questions about a possible difference in thermal resistance of genetically different groups of $M$. bovis. The spoligotyping technique is widely used to discriminate $M$. bovis isolates at a molecular level, and since 1990, many groups from different parts of the world have demonstrated the high genetic variability of this species (RODRIGUEZ et al., 2004).

A critical review by Lund et al. (2002) summarized the differences in thermal resistance of Mycobacterium paratuberculosis (the range was from under 2 to over 10 decimal reductions at $63^{\circ} \mathrm{C}$ for $30 \mathrm{~s}$ ) and considered that this variability can be explained by many factors, such as the strains used.
Considering that a) infection of cattle by $M$. bovis is endemic in many countries, including Brazil; b) this bacterium can be transmitted to humans through the consumption of milk and dairy products; and c) little information is available on the thermal resistance of $M$. bovis, and d) there are no reports on the influence of the genetic variability of the bacterium on thermal resistance, this study evaluated the inactivation of $M$. bovis spoligotypes in whole milk during pasteurization.

\section{Materials and Methods}

Milk, artificially contaminated with M. bovis, was submitted to conditions that mimicked the batch and flow pasteurization (LTLT and HTST) processes.

Four of the $12 \mathrm{M}$. bovis spoligotypes isolated by Rodriguez et al. (2004) from cattle slaughtered in the state of São Paulo were used. The 4 spoligotypes selected for this study were as follows: SB0121 and SB0295, which were the most frequently isolated spoligotypes, have been described previously in Europe but not in other Latin American countries; SB0120, also named BCG-like, has been previously observed in several countries in Europe, the Middle East, Japan, and South Africa; and a new spoligotype classified as SB1140 (RODRIGUEZ et al., 2004).

Each M. bovis spoligotype was individually cultured at $36^{\circ} \mathrm{C}$ for 10 days in Stonebrink-Leslie culture medium containing sodium monophosphate (Merck KGoA, Germany), potassium (J. T. Baker, Mexico), and sodium pyruvate (Vetec, Brazil). The inoculum (total volume $12 \mathrm{~mL}$ ) was prepared by suspending $0.3 \mathrm{~g}$ of the culture in $0.85 \%$ saline solution and $0.05 \%$ Tween 80 solution (Synth ${ }^{\circledR}$, Brazil). The inoculum ( $2 \mathrm{~mL}$ ) was used to inoculate $25 \mathrm{~mL}$ of ultra-high temperature (UHT) whole milk and an aliquot was removed to quantify the initial load (Li). For the assays, samples of the milk inoculated with the different spoligotypes were distributed into $5 \mathrm{~mL}$ aliquots in $16 \times 160 \mathrm{~mm}$ test tubes and placed in a water bath. 
For the evaluation of the LTLT pasteurization process, the water bath was maintained at $65^{\circ} \mathrm{C}$, and when the milk reached this target temperature, samples were removed every $5 \mathrm{~min}$ for $30 \mathrm{~min}$. The samples were labeled LT1 to LT7. A similar method was used for the evaluation of the HTST pasteurization process; however, 2 different water baths were used (Quimis ${ }^{\circledR}$, Brazil; Fanem ${ }^{\circledR}$, Brazil). The first water bath was set at $85^{\circ} \mathrm{C}$ and the second at $75^{\circ} \mathrm{C}$. In the first water bath, the samples were kept until the milk reached $75^{\circ} \mathrm{C}$, then one sample was removed and the others were transferred to the second water bath to maintain milk temperature at $75^{\circ} \mathrm{C}$. Subsequently, the samples were removed every $5 \mathrm{~s}$ for $20 \mathrm{~s}$. These samples were labeled HT1 to HT5. Each pasteurization process was performed three times.

The enzymatic control of the pasteurization processes was investigated through the analysis of alkaline phosphatase (Laborclin $\AA$, Brazil) and peroxidase (BRASIL, 2006) in samples of raw milk subjected to the thermal processes, along with the experimental samples. An uninoculated sample of the UHT whole milk was used to monitor the temperature of the product during the thermal treatments.

In addition, milk heating curve was studied. Milk temperature was recorded seven times, every $20 \mathrm{~s}$, until the milk reached target temperature $\left(65^{\circ} \mathrm{C}\right.$ and $\left.75^{\circ} \mathrm{C}\right)$.

To quantify M. bovis, the samples were subjected to serial decimal dilutions in $0.1 \%$ peptone water (BD DIFCO, France) and $0.1 \mathrm{~mL}$ from each dilution was spread, in duplicates, onto the surface of Stonebrink-Leslie medium prepared in cell culture flasks (Techno Plastic Products Ag, Switzerland). Colony counts were performed after 45 days of growth at $37^{\circ} \mathrm{C}$. The dilution chosen for counting produced between 10 to 150 colonies and the results were expressed as $\log _{10}$ colony-forming units per $\mathrm{mL}\left(\mathrm{CFU} \mathrm{mL} \mathrm{m}^{-1}\right)$ of milk.
The effects of the pasteurization processes on the CFU decay of the different $M$. bovis spoligotypes was measured for the heating (Li-LT1 and Li-HT1) and target temperature maintenance (LT1-LT7 and HT1-HT5) phases.

The comparison of the decay values of the $M$. bovis spoligotypes for each pasteurization process was performed using the Mann-Whitney test, whereas the differences in the decay values of each spoligotype for the slow and fast pasteurization processes were compared using the Wilcoxon test. The analyses were performed using the Minitab ${ }^{\circledR}$ software, version 16.2.2 (Minitab Inc., USA).

\section{Results and Discussion}

In all the raw milk controls, alkaline phosphatase and peroxidase enzymes were active, however, only the peroxidase remained active after the thermal treatment, demonstrating that the thermal processes tested and the official pasteurization parameters (BRASIL, 1952) were equivalent.

The CFU decay values for M. bovis are shown in Table 1. There were no significant variations in the CFU counts during the target temperature maintenance phase of both pasteurization processes (data not presented). Furthermore, there were no significant differences in the decay values of the different spoligotypes or the spoligotypes subjected to the LTLT and HTST pasteurization processes. However, the data suggested that the SB1140 spoligotype was more resistant to heat because it exhibited a lower decay value (Table 1). This observation could indicate a trend linked to its genetic composition. The confirmation of this hypothesis will require further testing using a larger number of samples.

Table 1 demonstrates that there was an increase in the decay value during the heating phase of both the LTLT and HTST pasteurization processes (average duration $140 \mathrm{~s}$ and $120 \mathrm{~s}$, respectively, shown in Figure 1) compared to the target 
temperature maintenance phase (duration $30 \mathrm{~min}$ and $20 \mathrm{~s}$, respectively). The extended time could explain the high efficiency of heating phase of
HTST process, but could not explain this for LTLT process, especially considering the time of exposure to temperatures at which bacterial death occurs.

Table 1. Decay rate of Mycobacterium bovis during the thermal treatment of whole milk in water bath, mimicking the low-temperature long-time and high-temperature short-time pasteurization processes.

\begin{tabular}{ccccccc}
\hline \multirow{2}{*}{$\begin{array}{c}\text { Spoligotype tested } \\
\text { (number of repetitions) }\end{array}$} & \multicolumn{5}{c}{$\begin{array}{c}\text { LTLT pasteurization } \\
\left(65^{\circ} \mathrm{C} \text { for } 30 \mathrm{~min}\right)\end{array}$} & \multicolumn{3}{c}{$\begin{array}{c}\text { HTST pasteurization } \\
\left(75^{\circ} \mathrm{C} \text { for } 20 \mathrm{~s}\right)\end{array}$} \\
\cline { 2 - 7 } & Heating $^{1}$ & Maintenance $^{2}$ & Sum & Heating $^{1}$ & Maintenance $^{2}$ & Sum \\
\hline $\begin{array}{c}\text { SB0120 } \\
(\mathrm{n}=3)\end{array}$ & 5.2 & 0.5 & 5.7 & 5.3 & 0.2 & 5.5 \\
$\begin{array}{c}\text { SB0121 } \\
(\mathrm{n}=3)\end{array}$ & 3.7 & 0.4 & 4.1 & 3.4 & 0.3 & 3.7 \\
$\begin{array}{c}\text { SB0295 } \\
(\mathrm{n}=3)\end{array}$ & 3.7 & 0.5 & 4.2 & 4.1 & 0.0 & 4.1 \\
$\begin{array}{c}\text { SB1140 } \\
(\mathrm{n}=3)\end{array}$ & 0.1 & 0.3 & 0.4 & 2.8 & 0.6 & 3.4 \\
\hline
\end{tabular}

${ }^{1}$ period until the milk reaches the target temperature $\left(65^{\circ} \mathrm{C}\right.$ or $\left.75^{\circ} \mathrm{C}\right)$

${ }^{2}$ period of maintenance of the target temperature ( $30 \mathrm{~min}$ or $\left.20 \mathrm{~s}\right)$.

Figure 1. Heating curve of milk samples in the water bath (WB) at $65^{\circ} \mathrm{C}$ and $85^{\circ} \mathrm{C}$.

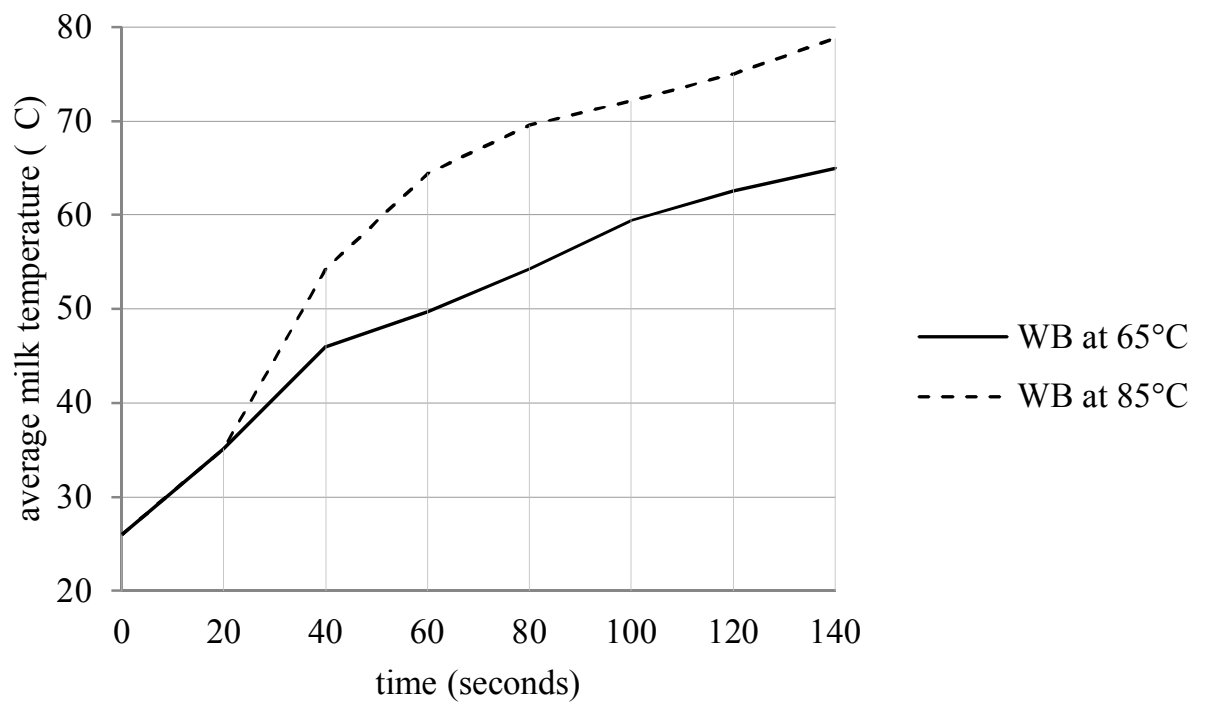

Similarly, in a study by Grant et al. (1996) investigating the resistance of $M$. paratuberculosis under LTLT pasteurization conditions, a large reduction in the microbial load was observed during the first $10 \mathrm{~min}$, followed by a small alteration in the microbial load until the end of the 30 min process. Sung and Collins (1998) suggested that the agent is capable of "adapting" to the rising temperature during heating, likely through the induction of a heat-shock protein or other elements that protect the organism from the deleterious effects of heat during the subsequent maintenance phase. When $M$. paratuberculosis was inoculated into an unheated substrate, the authors observed a $1 \log \mathrm{CFU} \mathrm{mL}^{-1}$ 
reduction after $90 \mathrm{~s}$ at $71^{\circ} \mathrm{C}$, whereas a reduction of $6 \log \mathrm{CFU} \mathrm{mL} \mathrm{m}^{-1}$ was observed during the $90 \mathrm{~s}$ when the inoculation was performed in a substrate already heated to that temperature.

In the literature, the small numbers of reports on thermal death of mycobacteria (M. bovis in particular) are old and few reports have been published since the 1960s. Furthermore, there are no reports regarding the thermal death pattern of $M$. bovis isolates circulating in Brazil. Kells and Lear (1960) observed that LTLT pasteurization led to the decay of $M$. bovis of 4 or more logarithmic cycles, which is similar to the values observed in this study with the exception of the SB1140 spoligotype. However, these and other authors (GRANT et al., 1996; HARRINGTON; KARLSON, 1965) observed the complete death of the M. bovis inoculum following the pasteurization of the milk, which was not observed in this study. Notably, the studies used an initial load similar to that used in this study $\left(10^{7} \mathrm{CFU}\right.$ M. bovis $\left.\mathrm{mL}^{-1}\right)$, with the exception of Harrington and Karlson (1965) who did not report the initial load of the agent. Despite the relevance of comparing the data from different studies, it is important to remember that there are differences between the tests reported here and those described in the literature, particularly with regards to the strain used, the agent quantification method, the time of inoculum addition to the substrate, and the characteristics of the substrate, pasteurization simulation system, and culture medium.

Based on the worst performance observed in this study, specifically the SB1140 spoligotype in the LTLT pasteurization process, one can speculate that in the worst case scenario of the natural contamination of a cow's milk $\left(10^{2}\right.$ to $10^{5}$ bacilli $\mathrm{mL}^{-}$ 1) (BALL, 1943; WILSON, 1948) the pasteurization process would not destroy the entire contaminating load. However, at farm and dairy plant levels, contaminated milk is mixed with uncontaminated milk, which reduces the initial load.
Based on the main observation of this study, i.e., the LTLT and HTST pasteurization processes considerably reduce but do not eliminate the $M$. bovis load in the milk, one can assume there is a risk to the milk- and dairy product-consuming population in countries where bovine tuberculosis is endemic, such as Brazil. However, considering the uncertainty of the initial M. bovis load in the milk under natural conditions, the dilution effect of the bacteria in bulk milk, the minimum infecting oral dose for humans, and the genotype diversity of $M$. bovis circulating in the Brazilian cattle population there is an urgent need for more studies in this area. Importantly, the tests must be performed on recent isolates and involve short culture time in the laboratory because successive passages in culture media can lead to increased thermal resistance (MERKAL et al., 1981; SUNG; COLLINS, 1998).

There is no evidence that pasteurized milk or dairy products currently contribute significantly to cases of tuberculosis in humans. However, little attention has been given to the differentiation of the M. tuberculosis species complex because from a clinical point of view, the diseases are similar and the treatment does not depend on the characterization of the bacteria (AYELE et al., 2004; DE LA RUADOMENECH et al., 2006; THOEN et al., 2010).

No differences were observed in the thermal resistance of the spoligotypes tested or in the decay of the CFU $\mathrm{mL}^{-1}$ of milk between the LTLT and HTST pasteurization processes. The heating phase was more effective at reducing the $M$. bovis load than the target temperature maintenance phase $\left(65^{\circ} \mathrm{C}\right.$ for $30 \mathrm{~min}$ and $75^{\circ} \mathrm{C}$ for $20 \mathrm{~s}$, respectively).

\section{Acknowledgements}

The authors acknowledge the financial support from CNPq and FAPESP. 


\section{References}

AYELE W. Y.; NEILL S. D.; ZINSSTAG, J.; WEISS, M. G., PAVLIK, I. Bovine tuberculosis: an old disease but a new threat to Africa. International Journal of Tuberculosis and Lung Disease, v. 8, n. 8, p. 924-937, 2004.

BAHIENSE, L.; ÁVILA, L. N. de; BAVIA, M. E.; AMAKU, M.; DIAS, R. A.; GRISI-FILHO, J. H. H.; FERREIRA, F.; TELLES, E. O.; GONÇALVES, V. S. P.; HEINEMANN, M. B.; FERREIRA NETO, J. S. Prevalence and risk factors for bovine tuberculosis in the State of Bahia, Brazil. Semina: Ciências Agrárias, Londrina, v. 37, n. 5, p. 3549-3560, 2016. Suplemento 2.

BALL, C. O. Short Time pasteurization of milk. Industrial \& Engineering Chemistry, v. 35, p. 71-84, 1943.

BARBIERI, J. M.; OLIVEIRA, L. F.; DORNELES, E. M. S.; MOTA, A. L. A. A.; GONÇALVES, V. S. P.; MALUF, P. P.; FERREIRA NETO, J. S.; FERREIRA, F.; DIAS, R. A.; TELLES, E. O.; GRISI-FILHO, J. H. H.; HEINEMANN, M. B.; AMAKU, M.; LAGE, A. P. Epidemiological status of bovine tuberculosis in the state of Minas Gerais, Brazil, 2013. Semina: Ciências Agrárias, Londrina, v. 37, n. 5, p. 3531-354, 2016. Suplemento 2.

BRASIL. Ministério da Agricultura, Pecuária e Abastecimento. Secretaria de Defesa Agropecuária. Instrução Normativa n.68, de 12 dez. 2006. Oficializa os métodos analíticos oficiais fisico-químicos, para controle de leite e produtos lácteos, em conformidade com o anexo desta Instrução Normativa, determinando que sejam utilizados nos Laboratórios Nacionais Agropecuários. Brasília, 2006. Available at: <http://extranet.agricultura. gov.br/sislegis-consulta/consultarLegislacao. do operacao $=$ visualizar\&id $=17472>$. Accessed at: 14 dez. 2015.

Presidência da República. Decreto no 30.691, de 29 de março de 1952. Aprova o novo Regulamento da Inspeção Industrial e Sanitária dos Produtos de Origem Animal. Ministério da Agricultura, Pecuária e Abastecimento. Departamento de Inspeção de Produtos de Origem Animal. Brasília: Casa Civil, 1952. Available at: <http://www.planalto.gov.br/ccivil_03/ decreto/1950-1969/D30691.htm>. Accessed at: 05 out 2016.

DE LA RUA-DOMENECH, R.; GOODCHILD, A. T.; VORDERMEIER, H. M.; HEWINSON, R. G.; CHRISTIANSEN, K.H.; CLIFTON-HADLEY, R. S. Ante mortem diagnosis of tuberculosis in cattle: a review of the tuberculin tests, gamma-interferon assay and other ancillary diagnostic techniques. Research in Veterinary Science, Amsterdam, v. 81, n. 2, p. 190-210, 2006.
DIAS, R. A.; STANOJLOVIC, F. M. U.; BELCHIOR, A. P. C.; FERREIRA, R. S.; GONÇALVES, R. C.; AGUIAR, R. S. C. B.; SOUSA, P. R.; SANTOS, A. M. A.; AMAKU, M.; FERREIRA, F.; TELLES, E. O.; GRISI-FILHO, J. H. H.; GONÇALVES, V. S. P.; HEINEMANN, M. B.; FERREIRA NETO, J. S. Prevalence and risk factors for bovine tuberculosis in the state of São Paulo, Brazil. Semina: Ciências Agrárias, Londrina, v. 37, n. 5, p. 3673-3684, 2016. Suplemento 2.

GALVIS, J. O. A.; GRISI-FILHO, J. H. H; COSTA, D.; SAID, A. L. P. R.; AMAKU, M.; DIAS, R. A.; FERREIRA, F.; GONÇALVES, V. S. P.; HEINEMANN, M. B.; TELLES, E. O.; FERREIRA NETO, J. S. Epidemiologic characterization of bovine tuberculosis in the state of Espírito Santo, Brazil. Semina: Ciências Agrárias, Londrina, v. 37, n. 5, p. 3567-3578, 2016. Suplemento 2.

GRANT, I. R; BALL, H. J.; NEILL, S. D.; ROWE, M. $\mathrm{T}$. Inactivation of Mycobacterium paratiberculosis in cows` milk at pasteurization temperatures. Applied and Environmental Microbiology, Washington, v. 62, n. 2, p. 631-636, 1996.

GRANT, I. R.; WILLIAMS, A. G.; ROWE, M. T.; MUIR, D. D. Efficacy of various pasteurization time-temperature conditions in combination with homogenization on inactivation of Mycobacterium avium subsp. paratuberculosis in milk. Applied and Environmental Microbiology, Washington, v. 71, n. 6, p. 2853-2861, 2005.

GUEDES, I. B.; BOTTENE, I. F. N.; MONTEIRO, L. A. R. C.; LEAL FILHO, J. M.; HEINEMANN, M. B.; AMAKU, M.; GRISI-FILHO, J. H. H.; DIAS, R. A.; FERREIRA, F.; TELLES, E. O.; GONÇALVES, V. S. P.; FERREIRA NETO, J. S. Prevalence and risk factors for bovine tuberculosis in the state of Mato Grosso do Sul, Brazil. Semina: Ciências Agrárias, Londrina, v. 37, n. 5, p. 3579-3588, 2016. Suplemento 2.

HARRINGTON, R.; KARLSON, A. G. Destruction of various kinds of mycobacteria in milk pasteurization. Applied Microbiology, Washington, v. 13, p. 494-495, 1965.

HUEBNER, R. J.; JELLISON, W. L.; BECK, M. D.; WILCOX, F. P. Q fever studies in southern California: III. Effects of pasteurization on survival of Coxiella burnetti in naturally infected milk. Public Health Reports, v. 63, n. 16, p. 499-511, 1948.

KAHLA，B.; BOSCHIROLI， M. L.; SOUISSI，F.; CHERIF, N.; BENZARTI, M.; BOUKADIDA, J.; HAMMAMI, S. Isolation and molecular characterization of Mycobacterium bovis from raw milk in Tunisia. African Health Sciences, Kampala, v. 11, p. S2-S5, 2011. 
KARLSON, A. G.; LESSEL, E. F. Mycobacterium bovis nom. nov. International Journal of Systematic Bacteriology, Ames, v. 20, n. 3, p. 273-282, 1970.

KELLS, H. R.; LEAR, S. A. Thermal death time curve of Mycobacterium tuberculosis var. bovis in artificially infected milk. Applied Microbiology, Washington, v. 8, n. 4, p. 234-236, 1960.

LEITE, C. Q. F.; ANNO, I. S.; LEITE, S. R. A.; ROXO, E.; MORLOCK, G. P.; COOKSEY, R. C. Isolation and identification of mycobacteria from livestock specimens and milk obtained in Brazil. Memórias do Instituto Oswaldo Cruz, Rio de Janeiro, v. 98, n. 3, p. 319-323, 2003.

LIMA, P. B.; NASCIMENTO, D. L.; ALMEIDA, E. C.; PONTUAL, K. A. Q.; AMAKU, M.; DIAS, R. A.; FERREIRA, F.; GONÇALVES, V. S. P.; TELLES, E. O.; GRISI-FILHO, J. H. H.; HEINEMANN, M. B.; SILVA, J. C. R.; FERREIRA NETO, J. S. Epidemiological situation of bovine tuberculosis in the state of Pernambuco, Brazil. Semina: Ciências Agrárias, Londrina, v. 37, n. 5, p. 3601-3610, 2016. Suplemento 2.

LUND, B. M.; GOULD, G. W.; RAMPLING, A. M. Pasteurization of milk and the heat resistance of Mycobacterium avium subsp. paratuberculosis: a critical review of the data. International Journal of Food Microbiology, Torino, v. 77, n. 3, p. 135-145, 2002.

MCDONALD, W. L.; O'RILEY, K. J.; SCHROEN, C. J.; CONDRON, R. J. Heat inactivation of Mycobacterium paratuberculosis in milk. Applied and Environmental Microbiology, Washington, v. 71, n. 4, p. 1785-1789, 2005.

MERKAL, R. S.; LYLE, P. S.; WHIPPLE, D. L. Heat inactivation of in vivo- and in vitro-grown mycobacteria in meat products. Applied and Environmental Microbiology, Washington, v. 41, n. 6, p. 1484-1485, 1981.

MESSELHÄUSSER, U.; KÄMPF, P.; HÖRMANSDORFER, S. Culture and molecular method for detection of Mycobacterium tuberculosis complex and Mycobacterium avium subsp. paratuberculosis in milk and dairy products. Applied and Environmental Microbiology, Washington, v. 78, n. 1, p. 295-297, 2012.

NÉSPOLI, J. M. B.; NEGREIROS, R. L.; AMAKU, M.; DIAS, R. A.; FERREIRA, F.; TELLES, E. O.; HEINEMANN, M. B.; GRISI-FILHO, J. H. H.; GONÇALVES, V. S. P.; FERREIRA NETO, J. S. Epidemiological situation of bovine tuberculosis in the state of Mato Grosso, Brazil. Semina: Ciências Agrárias, Londrina, v. 37, n. 5, p. 3589-3600, 2016. Suplemento 2.
NORTH, C. E.; PARK, W. H. Standards for milk pasteurization. American Journal of Hygiene, v. 7, p. 147-173, 1927.

OLDENBUSCH, C.; FROBISHER JÚNIOR, M.; SHRADER, J. H. Thermal death points of pathogenic bacteria in cream and ice cream mix. American Journal of Public Health, v. 20, n. 6, p. 615-618, 1930.

PAVLAS, M. Thermoresistance of mycobacteria. Acta Veterinaria Brno, Brno, v. 59, p. 65-71, 1990.

PEARCE, L. E.; TRUONG, H. T.; CRAWFORD, R. A.; YATES, G. F.; CAVAIGNAC, S.; DE LISLE, G. W. Effect of turbulent-flow pasteurization on survival of Mycobacterium avium subsp. paratuberculosis added to raw milk. Applied and Environmental Microbiology, Washington, v. 67, n. 9, p. 3964-3969, 2001.

PEREZ, A.; RENIERO, A.; FORTEIS, A.; MEREGALLI, S.; LÓPEZ, B.; RITACCO, V. Study of Mycobacterium bovis in milk using bacteriological methods and the polymerase chain reaction. Revista Argentina de Microbiologia, v. 34, n. 1, p. 45-51, 2002.

QUEIROZ, M. R.; GROFF, A. C. M.; SILVA, N. S.; GRISI-FILHO, J. H. H.; AMAKU, M.; DIAS, R. A.; TELLES, E. O.; HEINEMANN, M. B.; FERREIRA NETO, J. S.; GONÇALVES, V. S. P. FERREIRA, F. Epidemiological status of bovine tuberculosis in the state of Rio Grande do Sul, Brazil. Semina: Ciências Agrárias, Londrina, v. 37, n. 5, p. 3647-3658, 2016. Suplemento 2.

RIBEIRO, L. A.; GONÇALVES, V. S. P.; FRANCISCO, P. F. C.; MOTA, A. L. A. A.; NASCIMENTO, G. T.; LICURGO, J. B.; FERREIRA, F.; GRISI-FILHO, J. H. H.; FERREIRA NETO, J. S.; AMAKU, M.; DIAS, R. A.; TELLES, E. O.; HEINEMANN, M. B.; BORGES, J. R. J. Epidemiological status of bovine tuberculosis in the Federal District of Brazil. Semina: Ciências Agrárias, Londrina, v. 37, n. 5, p. 3561-3566, 2016. Suplemento 2.

ROCHA, W. V.; JAYME, V. S.; MOTA, A. L. A. A.; BRITO, W. M. E. D; PIRES, G. R. C; GRISI-FILHO, J. H. H; DIAS, R. A.; AMAKU, M.; TELLES, E. O.; HEINEMANN, M. B.; FERREIRA, F.; FERREIRA NETO, J. S.; GONÇALVES, V. S. P. Prevalence and herd-level risk factors of bovine tuberculosis in the State of Goiás, Brazil. Semina: Ciências Agrárias, Londrina, v. 37, n. 5, p. 3625-3628, 2016. Suplemento 2.

RODRIGUEZ, C. A. R.; ZUMARRAGA, M. J.; OLIVEIRA, E. M. D.; CATALDI, A. A.; ROMANO, M. I.; OTTO, H. H.; BONAFÉ, V. L.; FERREIRANETO, J. S. Caracterização molecular de isolados de Mycobacterium bovis do estado de São Paulo, Brasil, utilizando a técnica de spoligotyping. Arquivos do Instituto Biológico, São Paulo, v. 71, n. 3, p. 277-282, 2004. 
RUDOLER, N. Is Mycobacterium avium subsp. paratuberculosis an etiological factor in Crohn's disease? Visit of Infectious Diseases, Soroka Medical Center, Beer-Sheva, Israel. In: AIELO, S. E. The merck veterinary manual. $8^{\text {th }}$ ed. Whitehouse Station: Merck, 1998. Available at: http://www.isrvma.org Vol59 4ISM YCOBACTERIUMAVIUMSUBSP.doc. Accessed at: 05 out. 2016.

SILVA, M. C. P.; GONÇALVES, V. S. P.; MOTA, A. L. A. A.; KOLODA, M.; FERREIRA NETO, J. S.; GRISIFILHO, J. H. H; DIAS, R. A.; AMAKU, M.; TELLES, E. O.; FERREIRA, F.; HEINEMANN, M. B.; ALFIERI, A. A.; MULLER, E. E. Prevalence and herd-level risk factors for bovine tuberculosis in the state of Paraná, Brazil. Semina: Ciências Agrárias, Londrina, v. 37, n. 5, p. 3611-3624, 2016. Suplemento 2.

SINHA, R. N. Mycobacterium bovis (Chapter 11). In: International Dairy Federation, IDF/FIL. The significance of pathogenic microorganisms in raw milk. Belgium: International Dairy Federation. 1994. p. 141-166.

SUNG, N.; COLLINS, M. T. Thermal tolerance of Mycobacterium paratuberculosis. Applied and Environmental Microbiology, Washington, v. 64, n. 3, p. 999-1005, 1998.

THOEN, C. O.; LOBUE, P. A.; KANTOR, I. Why has zoonotic tuberculosis not received much attention? International Journal of Tuberculosis and Lung Disease, Paris, v. 14, n. 9, p. 1073-1074, 2010.
VELOSO, F. P.; BAUMGARTEN, K. D.; MOTA, A. L. A. A.; FERREIRA, F.; FERREIRA NETO, J. S.; GRISI-FILHO, J. H. H.; DIAS, R. A.; AMAKU, M.; TELLES, E. O.; HEINEMANN, M. B.; GONÇALVES, V. S. P. Prevalence and herd-level risk factors of bovine tuberculosis in the State of Santa Catarina, Brazil. Semina: Ciências Agrárias, Londrina, v. 37, n. 5, p. 3659-3672, 2016. Suplemento 2.

VENDRAME, F. B.; AMAKU, M.; FERREIRA, F.; TELLES, E. O.; GRISI-FILHO, J. H. H.; GONÇALVES, V. S. P.; HEINEMANN, M. B.; FERREIRA NETO, J. S.; DIAS, R. A. Epidemiologic characterization of bovine tuberculosis in the State of Rondônia, Brazil. Semina: Ciências Agrárias, Londrina, v. 37, n. 5, p. 3639-3646, 2016. Suplemento 2.

WILSON, G. S. The pasteurization of milk. London: Edward Arnold and Co., 1948. 212 p.

ZUMÁRRAGA, M. J.; SOUTULLO, A.; GARCÍA, M. I.; MARINI, R.; ABDALA, A.; TARABLA, H.; ECHAIDE, S.; LÓPEZ, M.; ZERVINI, E.; CANAL, A.; CATALDI, A. A. Detection of Mycobacterium bovis - infected dairy herds using PCR in bulk tank milk samples. Foodborne Pathogens and Disease, New Rochelle, v. 9, n. 2, p. 132137, 2012. 
